\title{
COMPARATIVE STUDY OF LOAD BEARING BLOCK MASONRY WORK IN HOUSING
}

\author{
M. T. S. Lakshmayya ${ }^{\# 1}$, R. Chiranjeevi Rahul ${ }^{* 2}$, \\ \# Department of Civil Engineering, GMR Institute of Technology, Rajam, India \\ ${ }^{1}$ lakshmayya888@gmail.com \\ * Department of Civil Engineering, Middle East College, Oman \\ ${ }^{2}$ rahul@mec.edu.om
}

\begin{abstract}
In order to improve the quality of construction and its sustainability without sacrificing strength, stability, performance, life of the structure and environmental friendly properties, usage of different eco-friendly materials are considered in load bearing masonry structure. In this study a suitable plan is selected and structural elements are designed as per Indian standard codes. Cost comparisons are made between building materials and labour required for construction of a ground plus four residential building using clay bricks, fly ash bricks and cellular light weight concrete blocks. The loads transferred to foundation from block masonry are also considered. From this, based on resources, cost optimized solutions are derived.
\end{abstract}

Keyword - Load bearing masonry, Clay bricks, Fly Ash bricks, Cellular Lightweight Concrete blocks.

\section{INTRODUCTION}

Until 1950's there were no engineering methods of designing masonry for buildings. Thicknesses of walls were considered from 'Rule-of-Thumb' tables given in building codes and regulations. As a result walls used to be very thick and masonry structures were found to be very uneconomical beyond 3 or 4 storeys. Buildings exceeding 3 or 4 storeys had thus to be constructed with steel or RCC frames. Since 1950's intensive theoretical and experimental research has been conducted on various aspects of masonry in advanced countries.

But, it is suited for a building in which floor area is subdivided into a large number of rooms of small or medium size and in which the floor plan is repeated in each storey throughout the height of the building. These conditions are met within residential buildings, schools, hostels, hospitals, nursing homes and certain types of administrative buildings. Extensive research, including large scale testing, has been carried out in regard to the behaviour of masonry which has enabled engineers and architects to design tall masonry structures on sound engineering principles with greater exactitude, economy and confidence.

There are many recent examples in other countries of well-designed 12 to 20 storeyed load bearing masonry buildings which have only 25 to $40 \mathrm{~cm}$ thick walls. This is in contrast to the 16 storey 'Monadnock Building' in Chicago designed by John Rort in 1891 with $180 \mathrm{~cm}$ thick brick walls at the base.

In India, there has not been much progress in the construction of tall load bearing masonry structures, mainly because quality of bricks generally manufactured in the country is poor, their normal strength being of the order of only $7 \mathrm{~N} / \mathrm{mm}^{2}$ to $10 \mathrm{~N} / \mathrm{mm}^{2}$. In many Western countries, bricks of even medium quality have crushing strength of $30 \mathrm{~N} / \mathrm{mm}^{2}$ to $50 \mathrm{~N} / \mathrm{mm}^{2}$. However, recently mechanized brick plants have been set up at a few places in the country which are producing bricks of strength $17.5 \mathrm{~N} / \mathrm{mm}^{2}$ to $25 \mathrm{~N} / \mathrm{mm}^{2}$. Thus, it should now be possible in some parts of the country to go in for 5 to 6 storeyed load bearing structures at costs less than those of RCC framed structures. With this development, structural design of load bearing masonry buildings has assumed additional importance in India as well. In fact, under the experimental projects scheme of the National Buildings Organization,Central Building Research Institute, Roorkee.

There is need and considerable scope in this country of intensifying experimental, research and study in the field of load bearing masonry in order to make better and more economical use of this wonderful and versatile building material, the brick. In India, we have been trying to keep pace to some extent with the developments taking place in other countries in regard to masonry.

In this context, the authors have studied various properties and usage of different eco-friendly construction materials like clay bricks, fly ash bricks and cellular light weight concrete blocks. A suitable plan is selected and structural elements are designed as per Indian standard codes with these materials. From this, based on resources, cost optimized solutions are derived. 


\section{LITERATURE REVIEW}

Many experiential studies and researches are carried out on load bearing masonry originated from different sources, they are clinical in construction industry mainly reducing the cost of construction and improving quality of structures built with them. Attempts were made early in U.S.S.R and empirical formulae based on brick strength to predict compressive strength of brick work was formulated (Onishchik. L. I, 1937 ${ }^{[15]}$ which helped a lot in further research, Large scale experimental study was also carried on this field in the western countries to improve the standards of house construction by research on usage of load bearing masonry with improved quality and reduced cost (Mathur. D. C and Berry. S, 1981) ${ }^{[14]}$. The importance of brick masonry walls as a support to structure was realised early and many studies were conducted in such aspects including load bearing walls (Davidson et al. 1952) ${ }^{[3]}$ (Cross and James. C, 1965) ${ }^{[2]}$. To ensure the stability and strength of multistoreyed brick structures up to 5 storeys, different realistic tests were also designed to check effect of wind loading, lateral strength of panels with pre-compression, floor/wall interaction, accidental removal of members and many other factors (Sinha B. P and Hendry A. W, 1976) ${ }^{[20]}$. In recent years the success of construction of buildings with load bearing masonry is such that not only medium storeyed buildings but buildings spanning 515 storeyes were constructed in Brazil on thin walls (Santos F. A et al., 2009) ${ }^{[18]}$, many studies were also carried on the potential of structural masonry in construction industry and the causes for the raise and decline of these type of constructions (Braj P. Sinha, 2002) ${ }^{[1]}$.

In Switzerland a series of laboratory tests on unreinforced masonry were conducted which made possible the construction of buildings up to 18 storeyes high and of 16 storey buildings with bearing walls measuring $5 \frac{7}{8} "(149.2 \mathrm{~mm})$ in thickness (Haller $\left.\mathrm{P}\right)^{[5]}$. In addition to this many construction companies and private organizations were conducting studies on the load bearing masonry made from various materials to reduce the cost of their construction projects. The effect of earth quake loading was also considered and its effects were also studied systematically in research process (Dina D'Ayala, 2014) ${ }^{[4]}$. Not only this, economy of load bearing masonry structures over conventional reinforced concrete structures were also studied and it was found that load bearing structures are significantly economical (Shashank B. S and Raghunath S, 2014) ${ }^{[19]}$, the load bearing masonry are again classified based on their material sources like burnt clay bricks, fly ash bricks, cellular lightweight concrete blocks (Chiranjeevi Rahul. R and Lakshmayya.M.T.S, 2014) ${ }^{[16]}$ or other types such as brick masonry and hollow concrete masonry and evaluation is made on their load bearing capabilities and economy (Rafiq Ahmad and Mohammad Iqbal Malik, 2014) ${ }^{[17]}$

In India also the trend of constructing structures with load bearing masonry is increasing rapidly because of its advantages, IIM Ahmadabad is a profound example for such structures in India, hence, In current study, cost of construction is compared for a multi storeyed load bearing structures using various types of materials like Clay bricks (IS 2212: 1991) ${ }^{[10]}$, Fly Ash bricks (IS 12894: 2002) ${ }^{[11]}$, Cellular Lightweight Concrete blocks (IS 2185: 2008 part IV) ${ }^{[12]}$. There by evaluating their scope in building construction. Design was done based on (SP $20(\mathrm{~S} \& T): 1991)^{[13]}$, the properties of these materials were evaluated following the Indian standard codes for usage of plain and reinforced concrete(IS 456-2000) ${ }^{[6]}$, code of practise for design loads, dead loads and live loads(IS 875 Part-I-1987) ${ }^{[7]}$, (IS 875 Part-II-1987) ${ }^{[8]}$, and code for usage of unreinforced masonry as structural members(IS 1905-1987) ${ }^{[9]}$.

\section{III.METHODOLOGY}

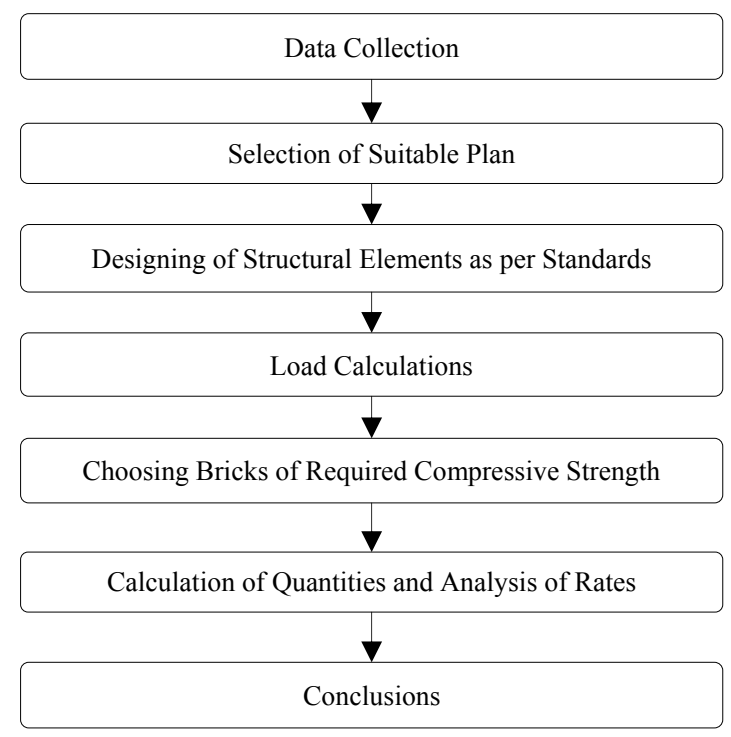

Fig.1. Methodology 
Data collection is performed and by analysing the data, suitable plan is selected, then the structural elements are designed following the standard specifications. After the design process the structural elements are introspected again and load calculations are performed. Then in the next stage bricks of required compressive strength are chosen for the structure based on the load calculations. Rate analysis of the items involved in the structure and labour costs are estimated, these costs are compared with the conventional materials used and necessary conclusions are made. This process is depicted in a flow chart above.

\section{IV.DESIGN CONSIDERATIONS}

In this study a suitable plan is selected as shown in Fig. 2 and structural elements are designed as per Indian standard codes.

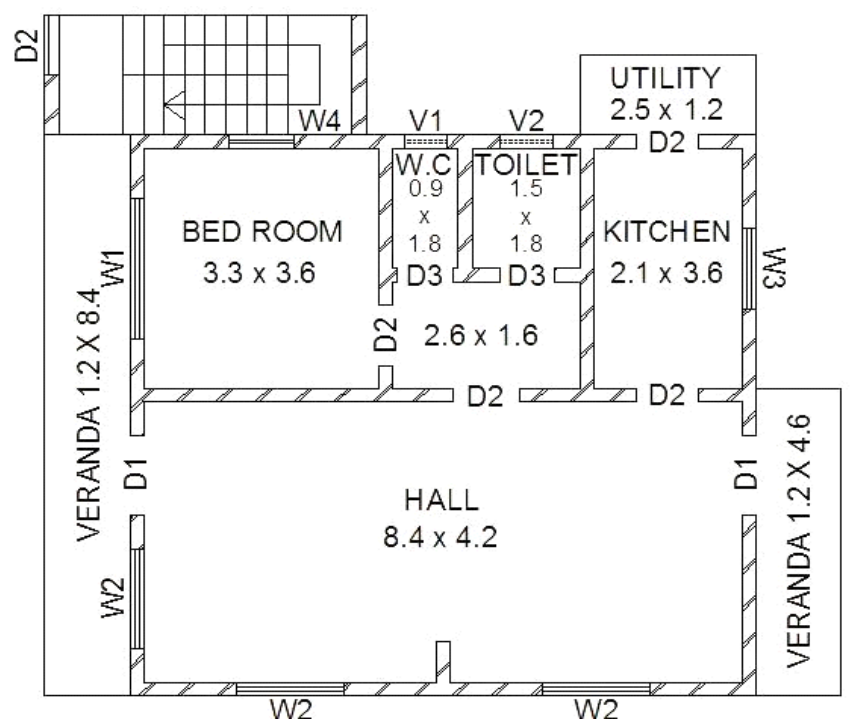

Fig. 2. Floor plan [Note: All dimensions are in $\mathrm{m}$.]

This structure is designed as ground plus four residential building with reinforced concrete slab supported on load bearing masonry. The slab thickness is taken as $120 \mathrm{~mm}$, masonry thickness as $200 \mathrm{~mm}$, floor height as $3.0 \mathrm{~m}$ $\mathrm{c} / \mathrm{c}$. door height is $2.1 \mathrm{~m}$, and window height is $1.5 \mathrm{~m}$. Floor plan is same for all floors.

\section{Slab:}

Size of the slab $\left(\mathrm{L}_{\mathrm{y}} \times \mathrm{L}_{\mathrm{x}}\right)=4.30 \mathrm{~m} \times 8.50 \mathrm{~m}$

Overall thickness of the slab $=120 \mathrm{~mm}$

$\frac{L_{y}}{L_{x}}=\frac{8.50}{4.30}=1.97(<2)$

Hence the slab is designed as two-way slab

Loads on roof slab

$\begin{array}{ll}\text { Self-weight } & : 3.0 \mathrm{kN} / \mathrm{m}^{2} \\ \text { Live load } & : 1.5 \mathrm{kN} / \mathrm{m}^{2} \\ \text { Total } & : 4.5 \mathrm{kN} / \mathrm{m}^{2}\end{array}$

Loads on slab for intermediate floors

Self-weight $: 3.0 \mathrm{kN} / \mathrm{m}^{2}$

Live load $\quad: 2.0 \mathrm{kN} / \mathrm{m}^{2}$

Unknown force $: 1.0 \mathrm{kN} / \mathrm{m}^{2}$

Total $\quad: 6.0 \mathrm{kN} / \mathrm{m}^{2}$

Loads on each walls:

Load on load bearing masonry wall from roof slab and intermediate slab are calculated.

Short span: $\frac{w L_{x}}{4}$

Long span: $\frac{w L_{x}}{2}\left(1-\frac{1}{2 r}\right)$; where $r=\frac{L_{y}}{L_{x}}$ 


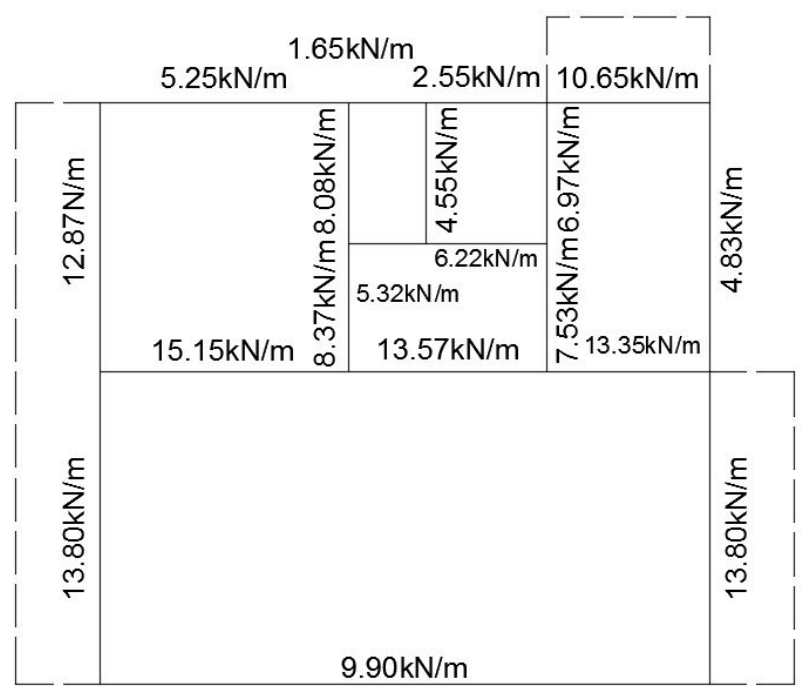

Fig. 3. Load on walls coming from roof slab

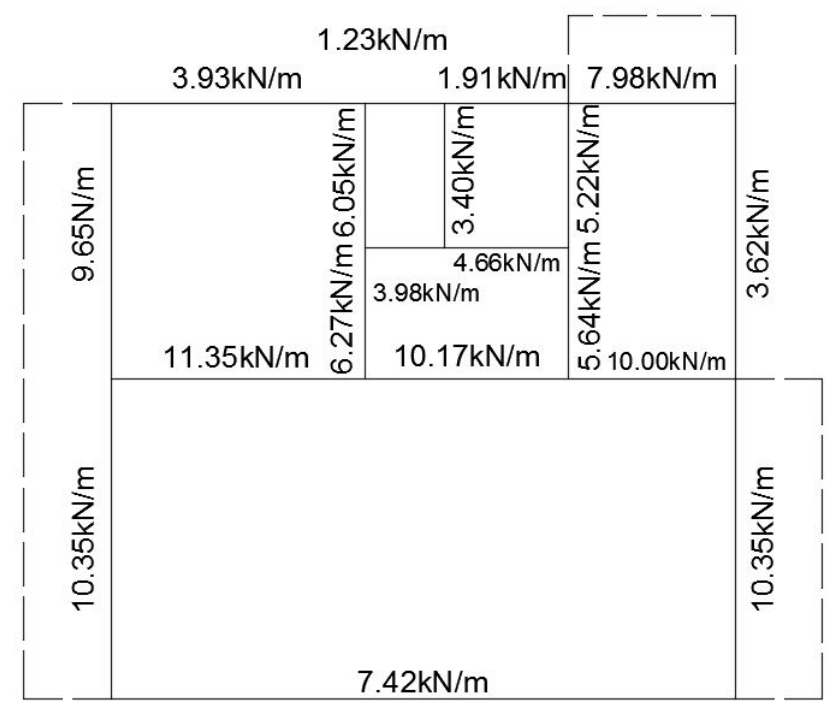

Fig. 4. Load on walls coming from intermediate floor slabs
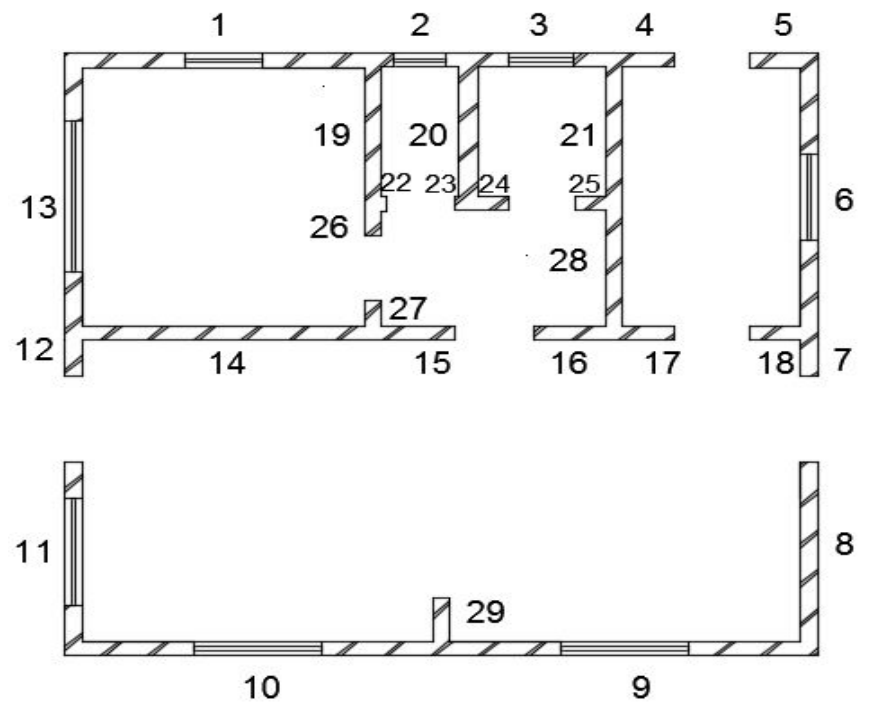

Fig. 5.Brick Work Elements 


\section{DESIGN OF A WALL CARRYING AXIAL LOAD}

\section{A. Masonry work in superstructure}

Maximum load from the roof slab of top floor is $11.35 \mathrm{kN} / \mathrm{m}$. whereas for remaining floors including ground floor maximum load from the slab is $15.15 \mathrm{kN} / \mathrm{m}$. Since wall 14 is bearing the maximum load.

Table1.Comparison of Characteristics of Different Masonry Blocks

\begin{tabular}{|c|c|c|c|}
\hline & Density $\left(\mathbf{k g f} / \mathbf{m}^{\mathbf{3}}\right)$ & Compressive strength(kgf/cm $\left.{ }^{2}\right)$ & Water absorption (\%) \\
\hline Clay Bricks & 2000 & Not less than75.00 & $25.00-30.00$ \\
\hline Fly Ash Bricks & 1800 & $75.00-110.00$ & $18.00-22.00$ \\
\hline CLC Blocks & 1200 & $65.00-120.00$ & $10.00-10.05$ \\
\hline
\end{tabular}

Table2. Values of Slenderness Ratio

\begin{tabular}{|c|c|c|c|c|c|c|c|c|c|}
\hline \multirow{2}{*}{$\begin{array}{c}\text { Brickwork } \\
\text { Element }\end{array}$} & \multicolumn{4}{|c|}{ Ground Floor, $\mathrm{t}=\mathbf{0 . 2 0}$} & \multicolumn{4}{|c|}{$1,2,3,4$ Floors, $t=0.20$} & \multirow{2}{*}{ Remarks } \\
\hline & $\mathbf{h}$ & 1 & $\mathbf{k}_{\mathbf{n}}$ & SR & $\mathbf{h}$ & 1 & $\mathbf{k}_{\mathbf{n}}$ & SR & \\
\hline 1 & 2.54 & 3.15 & 1.10 & 11.54 & 2.25 & 3.15 & 1.10 & 10.22 & \multirow{29}{*}{$\begin{array}{l}\text { Value of SR } \\
\text { shown in } \\
\text { the table is the } \\
\text { one that } \\
\text { is to be } \\
\text { taken into } \\
\text { consideration } \\
\text { for design }\end{array}$} \\
\hline 2 & 2.54 & 0.37 & 2.00 & 1.85 & 2.25 & 0.37 & 2.00 & 1.85 & \\
\hline 3 & 2.54 & 1.36 & 1.62 & 6.80 & 2.25 & 1.36 & 1.62 & 6.80 & \\
\hline 4 & 2.54 & 1.05 & 1.00 & 5.25 & 2.25 & 1.05 & 1.00 & 5.25 & \\
\hline 5 & 2.54 & 1.40 & 1.00 & 7.00 & 2.25 & 1.40 & 1.00 & 7.00 & \\
\hline 6 & 2.54 & 3.42 & 1.04 & 12.21 & 2.25 & 3.42 & 1.04 & 10.81 & \\
\hline 7 & 2.54 & 0.85 & 1.00 & 4.25 & 2.25 & 0.85 & 1.00 & 4.25 & \\
\hline 8 & 2.54 & 3.64 & 1.00 & 12.70 & 2.25 & 3.64 & 1.00 & 11.25 & \\
\hline 9 & 2.54 & 3.87 & 1.00 & 12.70 & 2.25 & 3.87 & 1.00 & 11.25 & \\
\hline 10 & 2.54 & 3.87 & 1.00 & 12.70 & 2.25 & 3.87 & 1.00 & 11.25 & \\
\hline 11 & 2.54 & 3.64 & 1.00 & 12.70 & 2.25 & 3.64 & 1.00 & 11.25 & \\
\hline 12 & 2.54 & 0.85 & 1.00 & 4.25 & 2.25 & 0.85 & 1.00 & 4.25 & \\
\hline 13 & 2.54 & 3.42 & 1.04 & 12.21 & 2.25 & 3.42 & 1.04 & 10.81 & \\
\hline 14 & 2.54 & 3.24 & 1.05 & 12.09 & 2.25 & 3.24 & 1.05 & 10.71 & \\
\hline 15 & 2.54 & 1.41 & 1.00 & 7.05 & 2.25 & 1.41 & 1.00 & 7.05 & \\
\hline 16 & 2.54 & 1.41 & 1.00 & 7.05 & 2.25 & 1.41 & 1.00 & 7.05 & \\
\hline 17 & 2.54 & 1.05 & 1.00 & 5.25 & 2.25 & 1.05 & 1.00 & 5.25 & \\
\hline 18 & 2.54 & 1.40 & 1.00 & 7.00 & 2.25 & 1.40 & 1.00 & 7.00 & \\
\hline 19 & 2.54 & 3.00 & 1.00 & 12.70 & 2.25 & 3.00 & 1.00 & 11.25 & \\
\hline 20 & 2.54 & 2.00 & 1.00 & 10.00 & 2.25 & 2.00 & 1.00 & 10.00 & \\
\hline 21 & 2.54 & 3.00 & 1.30 & 9.76 & 2.25 & 3.00 & 1.30 & 8.65 & \\
\hline 22 & 2.54 & 0.35 & 1.00 & 1.75 & 2.25 & 0.35 & 1.00 & 1.75 & \\
\hline 23 & 2.54 & 0.35 & 1.00 & 1.75 & 2.25 & 0.35 & 1.00 & 1.75 & \\
\hline 24 & 2.54 & 0.60 & 1.00 & 3.00 & 2.25 & 0.60 & 1.00 & 3.00 & \\
\hline 25 & 2.54 & 0.60 & 1.00 & 3.00 & 2.25 & 0.60 & 1.00 & 3.00 & \\
\hline 26 & 2.54 & 0.90 & 1.00 & 4.50 & 2.25 & 0.90 & 1.00 & 4.50 & \\
\hline 27 & 2.54 & 0.90 & 1.00 & 4.50 & 2.25 & 0.90 & 1.00 & 4.50 & \\
\hline 28 & 2.54 & 3.15 & 1.20 & 10.58 & 2.25 & 3.15 & 1.20 & 9.37 & \\
\hline 29 & 2.54 & 1.05 & 1.00 & 12.70 & 2.25 & 1.05 & 1.00 & 5.25 & \\
\hline
\end{tabular}

Note: In case of walls $\mathrm{SR}=\frac{h}{t \times k n}$ or $\frac{l}{t}$ and for design lesser of the two values is considered.

Determination of minimum compressive strength required for a masonry unit and grade of mortar mix is as follows.

Effective Height, $h=0.75 \mathrm{H}$ 
Effective length, $l=0.9 \mathrm{~L}$

$$
=0.75 \times 3.0=2.25 \mathrm{~m}
$$

$$
=0.9 \times 3.6=3.5 \mathrm{~m}
$$

Since effective height is less than effective length, SR based on height will control the design.

(From Table 9 of the Code for SR 12)

$$
\begin{aligned}
& \mathrm{t}=19 \mathrm{~cm} \\
& \mathrm{SR}=12.09 \approx 12.00
\end{aligned}
$$

Therefore Stress reduction factor $K_{s}$ with zero eccentricity

$$
=0.84
$$

1) Clay bricks

Unit weight of Clay Bricks of $2000 \mathrm{~kg} / \mathrm{m}^{3}$ density $=19.62 \mathrm{kN} / \mathrm{m}^{3}$

Self-weight of block work $=$ unit weight $\mathrm{x}$ length $\mathrm{x}$ breadth $\mathrm{x}$ height

$$
=19.62 \times 1.00 \times 0.20 \times 2.88=11.30 \mathrm{kN} / \mathrm{m}
$$

Total load for single floor is load on slab + self-weight of block work.

$$
\text { i.e., } \begin{aligned}
11.35+11.30 & =21.93 \mathrm{kN} / \mathrm{m} \text { (for } 5^{\text {th }} \text { floor) } \\
15.15+11.30 & =26.45 \mathrm{kN} / \mathrm{m} \text { (for remaining floors including ground floor) }
\end{aligned}
$$

Self-weight of block work in plinth $=19.62 \times 1.00 \times 0.20 \times 0.55=2.15 \mathrm{kN} / \mathrm{m}$

Therefore, total load at base of plinth $=130.60 \mathrm{kN} / \mathrm{m}$

Compressive stress in masonry at base of plinth

$$
\begin{aligned}
& =\frac{130.60 \times 1000}{20 \times 100} \\
& =65.30 \mathrm{~kg} / \mathrm{cm}^{2} \\
& =0.65 \mathrm{~N} / \mathrm{mm}^{2}
\end{aligned}
$$

With Shape modification factor $=1$, Basic Compressive stress of masonry

$$
=0.65 / 0.84=0.77 \mathrm{~N} / \mathrm{mm}^{2}
$$

Since modular bricks are used which have height to width ratio of 1.0, value of Shape modification factor (from Table 10 of the Code) equals to 1.2 .

Thus Basic Compressive stress required

$$
=0.77 / 1.1=0.70 \mathrm{~N} / \mathrm{mm}^{2}
$$

Referring to Table 8 of IS: 1905- 1987, masonry required is-bricks of strength $7.5 \mathrm{~N} / \mathrm{mm}^{2}$ and mortar of M1 grade. (M1 grade is 1:5 ratios of cement and sand respectively)

2) Fly Ash bricks

Unit weight of Fly Ash Bricks of $1800 \mathrm{~kg} / \mathrm{m}^{3}$ density $=17.65 \mathrm{kN} / \mathrm{m}^{3}$

Self-weight of block work $=$ unit weight $\mathrm{x}$ length $\mathrm{x}$ breadth $\mathrm{x}$ height

$$
=17.65 \times 1.00 \times 0.20 \times 2.88=10.16 \mathrm{kN} / \mathrm{m}
$$

Total load for single floor is load on slab + self-weight of block work.

$$
\text { i.e., } \begin{aligned}
11.35+10.16 & =21.51 \mathrm{kN} / \mathrm{m} \text { (for } 5^{\text {th }} \text { floor) } \\
15.15+10.16 & =25.31 \mathrm{kN} / \mathrm{m} \text { (for remaining floors including ground floor) }
\end{aligned}
$$

Self-weight of block work in plinth $=17.65 \times 1.00 \times 0.20 \times 0.55=1.94 \mathrm{kN} / \mathrm{m}$

Therefore, total load at base of plinth $=124.70 \mathrm{kN} / \mathrm{m}$

Compressive stress in masonry at base of plinth

$$
\begin{aligned}
& =\frac{124.70 \times 1000}{20 \times 100} \\
& =62.30 \mathrm{~kg} / \mathrm{cm}^{2} \\
& =0.62 \mathrm{~N} / \mathrm{mm}^{2}
\end{aligned}
$$

With Shape modification factor $=1$, Basic Compressive stress of masonry

$$
=0.62 / 0.84=0.74 \mathrm{~N} / \mathrm{mm}^{2}
$$

Since modular bricks are used which have height to width ratio of 1.75 , value of Shape modification factor (from Table 10 of the Code) equals to 1.0. 
Thus Basic Compressive stress required

$$
=0.74 / 1.0=0.74 \mathrm{~N} / \mathrm{mm}^{2}
$$

Referring to Table 8 of IS: $1905-1987$, masonry required is-bricks of strength $7.5 \mathrm{~N} / \mathrm{mm}^{2}$ and mortar of M1 grade. (M1 grade is 1:5 ratios of cement and sand respectively)

3) Cellular Light weight Concrete blocks

Unit weight of Cellular Light weight Concrete Blocks of $1200 \mathrm{~kg} / \mathrm{m}^{3}$ density $=11.77 \mathrm{kN} / \mathrm{m}^{3}$

Self-weight of block work $=$ unit weight $\mathrm{x}$ length $\mathrm{x}$ breadth $\mathrm{x}$ height

$$
=11.77 \times 1.00 \times 0.20 \times 2.88=6.78 \mathrm{kN} / \mathrm{m}
$$

Total load for single floor is load on slab + self-weight of block work.

$$
\text { i.e., } \begin{aligned}
11.35+11.30 & =21.93 \mathrm{kN} / \mathrm{m} \text { (for } 5^{\text {th }} \text { floor) } \\
15.15+11.30 & =21.93 \mathrm{kN} / \mathrm{m} \text { (for remaining floors including ground floor) }
\end{aligned}
$$

Self-weight of block work in plinth $=11.77 \times 1.00 \times 0.20 \times 0.55=1.30 \mathrm{kN} / \mathrm{m}$

Therefore, total load at base of plinth $=107.15 \mathrm{kN} / \mathrm{m}$

Compressive stress in masonry at base of plinth

$$
\begin{aligned}
& =\frac{107.15 \times 1000}{20 \times 100} \\
& =53.57 \mathrm{~kg} / \mathrm{cm}^{2} \\
& =0.53 \mathrm{~N} / \mathrm{mm}^{2}
\end{aligned}
$$

With Shape modification factor $=1$, Basic Compressive stress of masonry

$$
=0.53 / 0.84=0.63 \mathrm{~N} / \mathrm{mm}^{2}
$$

Since modular bricks are used which have height to width ratio of 1.0, value of Shape modification factor (from Table 10 of the Code) equals to 1.2 .

Thus Basic Compressive stress required

$$
=0.63 / 1.1=0.57 \mathrm{~N} / \mathrm{mm}^{2}
$$

Referring to Table 8 of IS: 1905- 1987, masonry required is-bricks of strength $7.5 \mathrm{~N} / \mathrm{mm}^{2}$ and mortar of M2 grade. (M2 grade is 1:6 ratios of cement and sand respectively)

B. Masonry works in staircase

Rise $=170 \mathrm{~mm}$

Tread $=290 \mathrm{~mm}$

No of risers $=18$ No's

Loads on Staircase:

Staircase slab thickness is 6" (i.e. $150 \mathrm{~mm}$ ) As per IS: 875

Self-weight $(6$ " thick $)=0.15 \times 1.00 \times 1.00 \times 25=3.75 \mathrm{kN} / \mathrm{m}^{2}$

Floor finish $\quad: 1.00 \mathrm{kN} / \mathrm{m}^{2}$

Total $\quad: 4.75 \mathrm{kN} / \mathrm{m}^{2}$

Vertical component:

Weight of waist slab $=0.15 \times 1.00 \times 1.00 \times 25 \times \frac{\sqrt{290^{2}+170^{2}}}{290}$

$$
\begin{aligned}
& =0.15 \times 1.00 \times 1.00 \times 25 \times 1.16 \\
& =4.35 \mathrm{kN} / \mathrm{m}^{2}
\end{aligned}
$$

$\begin{array}{ll}\text { Floor finish } & : 1.00 \mathrm{kN} / \mathrm{m}^{2} \\ \text { Weight of steps } & =\frac{170}{2 \times 1000} \times 1.00 \\ \text { Live load } & : 5.00 \mathrm{kN} / \mathrm{m}^{2} \\ \text { Total } & : 12.05 \mathrm{kN} / \mathrm{m}^{2}\end{array}$ 


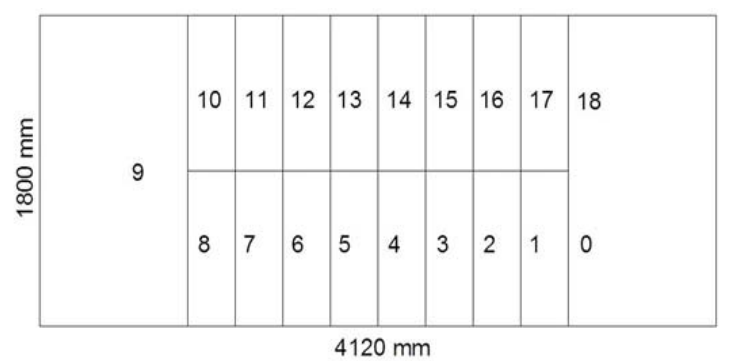

Fig. 6.Details of Stair Case

C. Comparison of loads on foundation from block work

Clay Brick:

Unit weight of Clay Bricks of $2000 \mathrm{~kg} / \mathrm{m}^{3}$ density $=19.62 \mathrm{kN} / \mathrm{m}^{3}$

Self-weight of block work $=$ unit weight $\mathrm{x}$ length $\mathrm{x}$ breadth $\mathrm{x}$ height

$$
=19.62 \times 1.00 \times 0.20 \times 2.88=11.30 \mathrm{kN} / \mathrm{m}
$$

Load from block work of 5 floors on to the foundation using Clay bricks is $56.50 \mathrm{kN} / \mathrm{m}$

Fly Ash Bricks:

Unit weight of Fly Ash Bricks of $1800 \mathrm{~kg} / \mathrm{m}^{3}$ density $=17.65 \mathrm{kN} / \mathrm{m}^{3}$

Self-weight of block work $=$ unit weight $\mathrm{x}$ length $\mathrm{x}$ breadth $\mathrm{x}$ height

$$
=17.65 \times 1.00 \times 0.20 \times 2.88=10.16 \mathrm{kN} / \mathrm{m}
$$

Load from block work of 5 floors on to the foundation using Fly Ash bricks is $50.80 \mathrm{kN} / \mathrm{m}$

Cellular Lightweight Concrete Blocks:

Unit weight of Cellular Lightweight Concrete Blocks of $1200 \mathrm{~kg} / \mathrm{m}^{3}$ density $=11.77 \mathrm{kN} / \mathrm{m}^{3}$

Self-weight of block work $=$ unit weight $\mathrm{x}$ length $\mathrm{x}$ breadth $\mathrm{x}$ height

$$
=11.77 \times 1.00 \times 0.20 \times 2.88=6.78 \mathrm{kN} / \mathrm{m}
$$

Load from block work of 5 floors on to the foundation using Cellular Lightweight Concrete blocks is $33.90 \mathrm{kN} / \mathrm{m}$

\section{VI.CALCULATION OF QUANTITIES}

Comparative statements of costs and materials are prepared for Clay bricks, Fly ash bricks and Cellular Lightweight Concrete blocks and percentage of saving is defined compared to Fly Ash bricks over Clay bricks, Cellular Lightweight Concrete blocks over Clay bricks, Cellular Lightweight Concrete blocks over Fly Ash

\begin{tabular}{|c|c|c|c|}
\hline & CLAY BRICKS & FLY ASH BRICKS & CLC BLOCKS \\
\hline \multicolumn{4}{|c|}{ BRICK WORK IN WALLS(for single floor): } \\
\hline Quantity & $25.00 \mathrm{cu} . \mathrm{m}$ & $25.00 \mathrm{cu} . \mathrm{m}$ & $25.00 \mathrm{cu} . \mathrm{m}$ \\
\hline Cement & 36.02bags & 24.50bags & 15.13bags \\
\hline Sand & $6.25 \mathrm{cu} . \mathrm{m}$ & 4.25cu.m & 3.20cu.m \\
\hline \multicolumn{4}{|c|}{ BRICK WORK IN STAIRCASE(for single floor): } \\
\hline Quantity & 2.00cu.m & 2.00cu.m & 2.00cu.m \\
\hline Cement & $2.47 \mathrm{bags}$ & 1.61bags & $1.21 \mathrm{bags}$ \\
\hline Sand & $0.51 \mathrm{cu} . \mathrm{m}$ & 0.33 cu.m & $0.26 \mathrm{cu} . \mathrm{m}$ \\
\hline \multicolumn{4}{|c|}{ BRICK WORK IN FOUNDATION: } \\
\hline Quantity & 23.00cu.m & $23.00 \mathrm{cu} . \mathrm{m}$ & $23.00 \mathrm{cu} . \mathrm{m}$ \\
\hline Cement & 28.53 bags & 18.44bags & 13.92bags \\
\hline Sand & 5.91cu.m & 3.86cu.m & 2.94cu.m \\
\hline \multicolumn{4}{|c|}{ PLASTERING: } \\
\hline Quantity & 300.00sq.m & 300.00sq.m & 300.00sq.m \\
\hline Cement & 31.50bags & $25.80 \mathrm{bags}$ & $21.60 \mathrm{bags}$ \\
\hline Sand & 5.25cu.m & 4.50cu.m & 3.75cu.m \\
\hline
\end{tabular}
bricks.

Table3. Quantities of Materials Required 
Table4. Item Rates

\begin{tabular}{|l|l|}
\hline Clay brick & Rs.6.00per brick \\
\hline Fly Ash brick & Rs.12.00per brick \\
\hline CLC block & Rs.3600 per cu. m \\
\hline Cement & Rs.300per Bag \\
\hline Sand & Rs.1200per cu. $\mathrm{m}$ \\
\hline Mason & Rs.450per no. \\
\hline Male coolie & Rs.300per no. \\
\hline
\end{tabular}

These rates are taken in to account on the basis of present construction rates in Visakhapatnam and rates are collected by conducting a survey to the construction sites, builders and material suppliers and quantity of work done per a day by a mason and a coolie is considered from the data collected from the experienced builders and masons considering the weight, size and shape of clay bricks, fly ash bricks and Cellular Lightweight Concrete blocks.

Table5. Quantities of Item and Labour Required

\begin{tabular}{|c|c|c|c|}
\hline & CLAY BRICKS & FLY ASH BRICKS & CLC BLOCKS \\
\hline \multicolumn{4}{|c|}{ BLOCK WORK IN WALLS: } \\
\hline Bricks & 62,500 no’s & 15,395 no’s & 5,210 no’s \\
\hline Cement & 180.10 bags & $122.50 \mathrm{bags}$ & 76.65 bags \\
\hline Sand & $31.25 \mathrm{cu} . \mathrm{m}$ & $21.25 \mathrm{cu} . \mathrm{m}$ & 16.00cu.m \\
\hline Mason & 84 no's & 63 no’s & 32 no’s \\
\hline Coolie & 42 no’s & 32 no’s & 16 no’s \\
\hline \multicolumn{4}{|c|}{ BLOCK WORK IN STAIRCASE: } \\
\hline Bricks & 5,000 no's & 1,235 no's & 420 no’s \\
\hline Cement & 12.35 bags & 8.05 bags & 6.05 bags \\
\hline Sand & $2.55 \mathrm{cu} . \mathrm{m}$ & 1.65cu.m & $1.30 \mathrm{cu} . \mathrm{m}$ \\
\hline Mason & 7 no’s & 5 no’s & 3 no’s \\
\hline Coolie & 4 no’s & 3 no's & 2 no’s \\
\hline \multicolumn{4}{|c|}{ BLOCK WORK IN FOUNDATION: } \\
\hline Bricks & 57,500 no’s & 14,165 no’s & 4,795 no's \\
\hline Cement & 142.65 bags & 92.20 bags & 69.6 bags \\
\hline Sand & 29.55cu.m & 19.3cu.m & 14.70cu.m \\
\hline Mason & 13 no’s & 9 no's & 5 no's \\
\hline Coolie & 7 no’s & 5 no's & 3 no's \\
\hline \multicolumn{4}{|c|}{ PLASTERING: } \\
\hline Cement & 157.50 bags & 129.00 bags & 108.00 bags \\
\hline Sand & $26.25 \mathrm{cu} . \mathrm{m}$ & $22.5 \mathrm{cu} . \mathrm{m}$ & 18.75cu.m \\
\hline Mason & 162 no’s & 121 no’s & 81 no’s \\
\hline Coolie & 162 no’s & 121 no’s & 81 no’s \\
\hline
\end{tabular}


Table6. Cost of Item and Labour Required

\begin{tabular}{|c|c|c|c|}
\hline & CLAYBRICKS & FLYASH BRICKS & CLCBLOCKS \\
\hline \multicolumn{4}{|c|}{ BRICK WORK IN WALLS: } \\
\hline Bricks & Rs. $3,75,000.00$ & Rs. $1,84,740.00$ & Rs. $4,42,850.00$ \\
\hline Cement & Rs. $54,030.00$ & Rs. $36,750.00$ & Rs.22,695.00 \\
\hline Sand & Rs. $37,500.00$ & Rs. $25,500.00$ & Rs. $19,200.00$ \\
\hline Mason & Rs.37800.00 & Rs. $28,350.00$ & Rs. $14,400.00$ \\
\hline Coolie & Rs. $12,600.00$ & Rs. $9,600.00$ & Rs. $4,800.00$ \\
\hline \multicolumn{4}{|c|}{ BRICK WORK IN STAIRCASE: } \\
\hline Bricks & Rs. $30,000.00$ & Rs. $14,820.00$ & Rs.35,700.00 \\
\hline Cement & Rs.3,705.00 & Rs. $2,415.00$ & Rs. $1,815.00$ \\
\hline Sand & Rs.3,060.00 & Rs. $1,980.00$ & Rs. $1,560.00$ \\
\hline Mason & Rs. $3,150.00$ & Rs. $2,250.00$ & Rs. $1,350.00$ \\
\hline Coolie & Rs. $1,200.00$ & Rs. 900.00 & Rs. 600.00 \\
\hline \multicolumn{4}{|c|}{ BRICK WORK IN FOUNDATION: } \\
\hline Bricks & Rs. $3,45,000.00$ & Rs. $1,69,980.00$ & Rs. $4,07,575.00$ \\
\hline Cement & Rs.42,795.00 & Rs.27,660.00 & Rs.20,880.00 \\
\hline Sand & Rs. $35,460.00$ & Rs.23,160.00 & Rs. $17,640.00$ \\
\hline Mason & Rs. $5,850.00$ & Rs. $4,050.00$ & Rs.2,250.00 \\
\hline Coolie & Rs. $2,100.00$ & Rs. $1,500.00$ & Rs. 900.00 \\
\hline \multicolumn{4}{|c|}{ PLASTERING: } \\
\hline Cement & Rs. $47,250.00$ & Rs.38,700.00 & Rs. $32,400.00$ \\
\hline Sand & Rs.31,500.00 & Rs. $27,000.00$ & Rs.22,500.00 \\
\hline Mason & Rs.72,900.00 & Rs.54,450.00 & Rs. $36,450.00$ \\
\hline Coolie & Rs. $48,600.00$ & Rs.36,300.00 & Rs. $24,300.00$ \\
\hline TOTAL & Rs.11,89,500.00 & Rs.6,90,105.00 & Rs.11,09,865.00 \\
\hline
\end{tabular}

The Cost of building (Material and Labour) as per the plan shown in the Fig.2 is as follows,

- The cost of G+4 Residential building with Clay Brick is Rs.1,486.87/- per sq.m.

- The cost of G+4 Residential building with Fly Ash Brick is Rs.826.63/- per sq.m.

- The cost of G+4 Residential building with CLC Block is Rs.1,387.33/- per sq.m.

- The cost of G+4 Residential building with Clay Brick is Rs.20,677.20/- per cu.m.

- The cost of G+4 Residential building with Fly Ash Brick is Rs.11,397.60/- per cu.m.

- The cost of G+4 Residential building with CLC Block is Rs.20,157.80/- per cu.m.

\section{CONCLUSIONS}

- $\quad$ Finally, by using Fly Ash Bricks Rs.4,99,395/- and Rs.4,19,760/- may be saved for this G+4 residential building over Clay Bricks and Cellular Lightweight Concrete Blocks respectively means around 42\% and $38 \%$ of cost of the construction can be reduced using Fly Ash Bricks.

- By using Fly Ash bricks 10.09\% of loads are reduced over Clay bricks. By using Cellular Lightweight Concrete blocks $40.00 \%$ of loads are over Clay bricks. By using Cellular Lightweight Concrete blocks $10.09 \%$ of loads are over Fly Ash bricks.

- By using Fly Ash bricks with cement mortar mix M2 (1:6), 34.96\% of cement and 36.00\% of sand can be reduced per cu.m of brickwork over Clay bricks with cement mortar mix M2 (1:6), as number of mortar joins are less when compared with clay bricks. 
- By using Cellular Lightweight Concrete blocks with cement mortar mix M2(1:6), 51.22\% of cement and $48.00 \%$ of sand can be reduced per cu.m of brickwork over Clay bricks with cement mortar mix M2(1:6), as number of mortar joins are less when compared with Clay bricks.

- By using Cellular Lightweight Concrete blocks with cement mortar mix M2(1:6), $25.00 \%$ of cement and $18.75 \%$ of sand can be reduced per cu.m of brickwork over Fly Ash bricks with cement mortar mix M2(1:6), as number of mortar joins are less when compared with Fly Ash bricks.

- By using Fly Ash bricks, $31.95 \%$ of cement and 32.00\% of sand can be reduced per sq.m of plastering work over Clay bricks with cement mortar mix M1(1:5).

- By using Cellular Lightweight Concrete blocks, $58.33 \%$ of cement and $48.00 \%$ of sand can be reduced per sq.m of plastering work over Clay bricks with cement mortar mix M1(1:5).

- By using Cellular Lightweight Concrete blocks, $25.00 \%$ of cement and $18.75 \%$ of sand can be reduced per sq.m of plastering work over Fly Ash bricks with cement mortar mix M1(1:5).

- By using Fly Ash bricks, cost of labour for masonry block work in superstructure can be reduced by $49.41 \%$ by using Fly Ash bricks when compared with clay bricks. Whereas by using Cellular Lightweight Concrete blocks 61.91\% savings over clay bricks and 49.41\% savings over Fly Ash bricks.

- By using Fly Ash bricks, cost of labour for masonry block work in foundation can be reduced by $30.19 \%$ by using Fly Ash bricks when compared with clay bricks. Whereas by using Cellular Lightweight Concrete blocks $60.38 \%$ savings over clay bricks and $43.25 \%$ savings over Fly Ash bricks.

- By using Fly Ash bricks, cost of labour for plastering work can be reduced by $25.31 \%$ by using Fly Ash bricks when compared with clay bricks. Whereas by using Cellular Lightweight Concrete blocks 50.00\% savings over clay bricks and 33.06\% savings over Fly Ash bricks.

- From the above statements, if cost is the factor Fly Ash bricks are suggested to use since it is cheaper and readily available all over. Also suggested by many organizations and Government to use Fly Ash in construction sector since, it is available in large quantities and even eco-friendly in nature.

- If time is the factor Cellular Lightweight Concrete blocks are suggested to use due to its size, shape and weight, work becomes easy and fast for labour in construction of block work and plastering work. As well as time required for construction may also be reduced.

- Having several advantages like low water absorption, high thermal insulation, high fire protection, high sound insulation and eco-friendly to environment Cellular Lightweight Concrete blocks can be used for block work constructions.

\section{ACKNOWLEDGMENT}

I humbly express my profound gratitude to Prof. B. V. Sarma and my parents for their support during the study period; I would also like to thank Dr. B. Harish, G. Aditya for their cooperation.

\section{REFERENCES}

[1] Braj P. Sinha, "Development and Potential of Structural Masonry", Seminário sobre Paredes de Alvenaria, P.B. Lourenço \& H. Sousa (Eds.), Porto, 2002

[2] Cross, James C. - "Introduction to Contemporary Bearing Walls" in Proc. National Brick and Tile Bearing Conference, Washington, 1965.

[3] Davidson, Robert L.; Fisher, T. and Associates; Monk, C. B. - "The brick walls are only support in a design for multi-storey buildings", Architectural Record, June, 1952.

[4] Dina D'Ayala, "Assesing sesmic vulnerability of masonary buildings", A hand book of sesmic risk analysis and management of civil infrastructure systems- Vol-3, pp-334-365, March 2014.

[5] Haller, P. - "The properties of load-bearing brickwork in perforated fired clay bricks for multi-storey buildings", Lib. Comm. 870, Garston, B.R.S., UK.

[6] IS: 456-2000- Code of Practice for Plain Reinforced Concrete.

[7] IS: 875 (Part-1) -1987- Code of Practice for Design Loads and Dead Loads

[8] IS: 875 (Part-2) -1987- Code of Practice for Design Loads and Live Loads.

[9] IS: 1905-1987-Code of Practice for Structural use of Unreinforced Masonry.

[10] IS: 2212:1991- Code of Practise for Clay brick works

[11] IS: 12894:2002- Code of practise for Fly Ash bricks

[12] IS: 2185:2008 part IV- Code of practise for Cellular light weight Concrete blocks

[13] SP 20(S\&T):1991- Hand book on Masonary design and Construction

[14] Mathur, D. C.; Berry, S. - "Role of Brickwork in Housing in Developing Countries like India; Case Studies"in Int. Seminar; Workshop on Planning, Design, Construction of Load-bearing Brick Buildings for Developing Countries, New Delhi, India, 1981.

[15] Onishchik, L. I. - Prohrost' i ustoichivost' kamennykh konstructsii (The Strength and Stability of Masonry Structures), O.N.T.L., USSR, 1937.

[16] R. Chiranjeevi Rahul, M.T.S. Lakshmayya. "A Study of Performance of Physical Properties of Preformed Foam Cellular Concrete Blocks against Burnt Clay Bricks and Fly Ash Bricks", Proceedings of the National Conference on New Trends in Civil Engineering (NTCE-2014), July 18-19, 2014.pp.129-131. 
[17] Rafiq Ahmad , Mohammad Iqbal Malik et.al. "Brick Masonry and Hollow Concrete Block Masonry - A Comparative Study", International Journal Of Civil And Structural Engineering Research (IJCSER) Vol. 1, Issue 1, pp: (14-21), Month: October 2013March 2014.

[18] Santos, F. A.; Sinha, B. P.; Roman, H. R. - "The effect of construction defect on the strength and behaviour of masonry structures"in Creative Systems in Structural andconstruction Engineering. Ed. by A. Singh, AA Balkema, Rotterdam, 2001, pp 587-591.

[19] Shashank B.S, S.Raghunath "Analysis and Design of Multi-storeyed load bearing reinforced masonry and framed structure", International Journal of Research in Engineering and Technology, (RRDCE-2014): Organized by Department of Civil Engineering, DR AIT. College of Engineering, Bangalore. eISSN: 2319-1163 pISSN: 2321-7308 Volume: 03 Special Issue: 06 May-2014 RRDCE page no 179-186.

[20] Sinha, B. P.; Hendry, A.W. - "Structural Testing of Brickwork in a Disused Quarry", Proc. Inst. Civil Engineers, Part 1, 1976, pp 153162. 